\title{
Bis coumarinyl bis triazolothiadiazinyl ethane derivatives: Synthesis, antiviral activity evaluation, and molecular docking studies
}

\author{
Sreenu Pavurala, Krishnaiah Vaarla, Rajeshkumar Kesharwani, Lieve \\ Naesens, Sandra Liekens \& Rajeswar Rao Vedula
}

To cite this article: Sreenu Pavurala, Krishnaiah Vaarla, Rajeshkumar Kesharwani, Lieve Naesens, Sandra Liekens \& Rajeswar Rao Vedula (2018) Bis coumarinyl bis triazolothiadiazinyl ethane derivatives: Synthesis, antiviral activity evaluation, and molecular docking studies, Synthetic Communications, 48:12, 1494-1503, DOI: 10.1080/00397911.2018.1455871

To link to this article: https://doi.org/10.1080/00397911.2018.1455871

View supplementary material $₫$

Published online: 23 May 2018.

Submit your article to this journal

山 Article views: 32

Q View related articles $\sqsubset$

View Crossmark data $\nearrow$ 


\title{
Bis coumarinyl bis triazolothiadiazinyl ethane derivatives: Synthesis, antiviral activity evaluation, and molecular docking studies
}

\author{
Sreenu Pavuralaa ${ }^{a}$ Krishnaiah Vaarla ${ }^{a}$, Rajeshkumar Kesharwani ${ }^{b}$, Lieve Naesensc, \\ Sandra Liekens ${ }^{c}$, and Rajeswar Rao Vedula ${ }^{a}$
}

aDepartment of Chemistry, National Institute of Technology, Warangal, India; 'Department of Biotechnology, National Institute of Technology, Warangal, India; 'Department of Microbiology and Immunology, Rega Institute for Medical Research, KU Leuven, Leuven, Belgium

\begin{abstract}
A series of novel 3,3'-(3,3'-(dihydroxy/hydroxyethane-1,2-diyl)bis $(7 \mathrm{H}$ $[1,2,4]$ triazolo[3,4-b][1,3,4]thiadiazine-6,3-diyl))bis(2H-chromen-2-ones) were prepared by the condensation of thiocarbohydrazide with tartaric acid or malic acid followed by various 3-(2-bromoacetyl)- $2 \mathrm{H}$ chromen-2-ones in two steps with good yields. All the synthesized compounds were characterized by analytical and spectral (IR, ${ }^{1} \mathrm{H} N M R$, ${ }^{13} \mathrm{C}$ NMR, and mass) data. These synthesized bis(triazolothiadiazinyl coumarin) compounds were evaluated for broad spectrum of antiviral activity. Among all the tested compounds, compound $\mathbf{5} \mathbf{f}$ exhibited antiviral activity against H1N1 virus. The molecular docking studies of these compounds against $\mathrm{H} 1 \mathrm{~N} 1$ neuraminidase enzyme were performed. The binding affinity and binding values were compared with standard drugs.
\end{abstract}

\section{GRAPHICAL ABSTRACT}<smiles></smiles>

\section{Antiviral activity}

Compound $5 \mathrm{EC}_{50}=\mathbf{2 0} \mu \mathrm{M}$ (Injfluenza $\mathrm{H}_{3} \mathrm{~N}_{2}$ )

Compound $5 \mathrm{EC}_{50}=\mathbf{4 0} \mu \mathrm{M}$ (Injfluenza $\mathrm{H}_{3} \mathrm{~N}_{2}$ )

\section{ARTICLE HISTORY}

Received 17 December 2017

\section{KEYWORDS}

Antiviral activity; coumarins; influenza virus; molecular docking; thiocarbohydrazide

\section{Introduction}

The development of effective therapeutic agents with simple, efficient, and environmentally benign methods is a great challenge to the scientific community. In recent years, emergence

CONTACT Rajeswar Rao Vedula rajeswarnitw@gmail.com @ Department of Chemistry, National Institute of Technology, Warangal 506 004, India.

Color versions of one or more of the figures in the article can be found online at www.tandfonline.com/lsyc.

(4) Supplemental data for this article can be accessed on the publisher's website. 
of drug resistance to viral strains is becoming a severe problem around the world. The main objective of the synthetic and pharmaceutical chemists is to design, synthesize, and formulate novel bio-active molecules.

Sulfur- and nitrogen-containing five- and six-membered heterocyclic compounds were reported for various biological activities. ${ }^{[1,2]}$ Coumarin is one of the naturally occurring heterocyclic compounds, which is commonly used as drugs and dyes. ${ }^{[3]}$ Synthetic and naturally occurring coumarins showed a broad range of pharmacological properties such as anticoagulant, ${ }^{[4]}$ antitumor, ${ }^{[5]}$ and anticonvulsant ${ }^{[6]}$ activities. Reports showed that coumarin and its derivatives possess anti-HIV, anticancerous activity in in vitro and in vivo models ${ }^{[7]}$ and it can also be used as triplet sensitizers. ${ }^{[8]}$ These derivatives are widely used as optical brighteners, ${ }^{[9]}$ pharmaceuticals ${ }^{[10]}$ and some of these analogues are highly fluorescent in nature. ${ }^{[11]}$

The heterocyclic compounds having coumarin with triazoles ring gained special attention of the researchers due to their extensive pharmacological properties. Molecules with 1,2,4-triazole ring system showed various biological properties such as antitubercular, ${ }^{[12]}$ diuretic, ${ }^{[13]}$ and hypoglycemic activity. ${ }^{[14]}$ Some marketed pharmaceuticals such as triazolam, ${ }^{[15]}$ alprazolam, ${ }^{[16]}$ and etizolam ${ }^{[17]}$ contain 1,2,4-triazole ring system.

Heteroatomic hybrid structures of triazolothiadiazines have received considerable attention from the scientific community, since they show a diverse range of biological activities like central nervous system (CNS) depressant ${ }^{[18]}$ and antioxidant. ${ }^{[19]}$ In addition, these

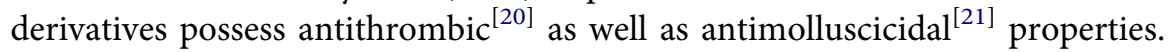

On account of the importance associated with coumarins and triazolothiadiazines in the field of synthetic and bioorganic medicinal chemistry, we have focused on the synthesis of novel molecules that comprises coumarin and triazolothiadiazines nucleus into a single molecular framework. In recent years, computer-aided drug designing and molecular modeling studies played a vital role in the field of medicinal chemistry to understand the mode of binding and molecular interactions of active molecules with proteins and their key active site residues which are helpful to explore the activity. Therefore, here we report the synthesis, antiviral evaluation and the molecular docking studies of bis coumarinyl bis triazolothiadiazinyl ethane derivatives.

\section{Results and discussion}

\section{Chemistry}

The title compounds bis coumarinyl bis triazolothiadiazinyl ethane derivatives (5a-k) were synthesized with good to excellent yields through simple, efficient, environmentally benign, and catalytic free reaction conditions through two-step synthetic method in a shorter reaction time. The target molecules were synthesized by the reaction of aliphatic dicarboxylic acids such as 1-tartaric acid (1a) and malic acid (1b) with thiocarbohydrazide (2) through simple fusion method to get the intermediated ethane-1,2-diyl bis (4-amino-4H-1,2,4-triazole-3-thiols) intermediate (3a, b), followed by the reaction with different substituted 3-(2-bromoacetyl)-2H-chromen-2-ones $(\mathbf{4 a - j})$ in the presence of ethanol solvent. All the newly synthesized compounds' structure was elucidated and confirmed by their analytical and spectral (IR, ${ }^{1} \mathrm{H}$ NMR, ${ }^{13} \mathrm{C} \mathrm{NMR}$, and mass) data and outlined in Scheme 1. Synthetic analogues $(\mathbf{5 a}-\mathbf{k})$ with their yield and reaction condition are shown in Table 1. 


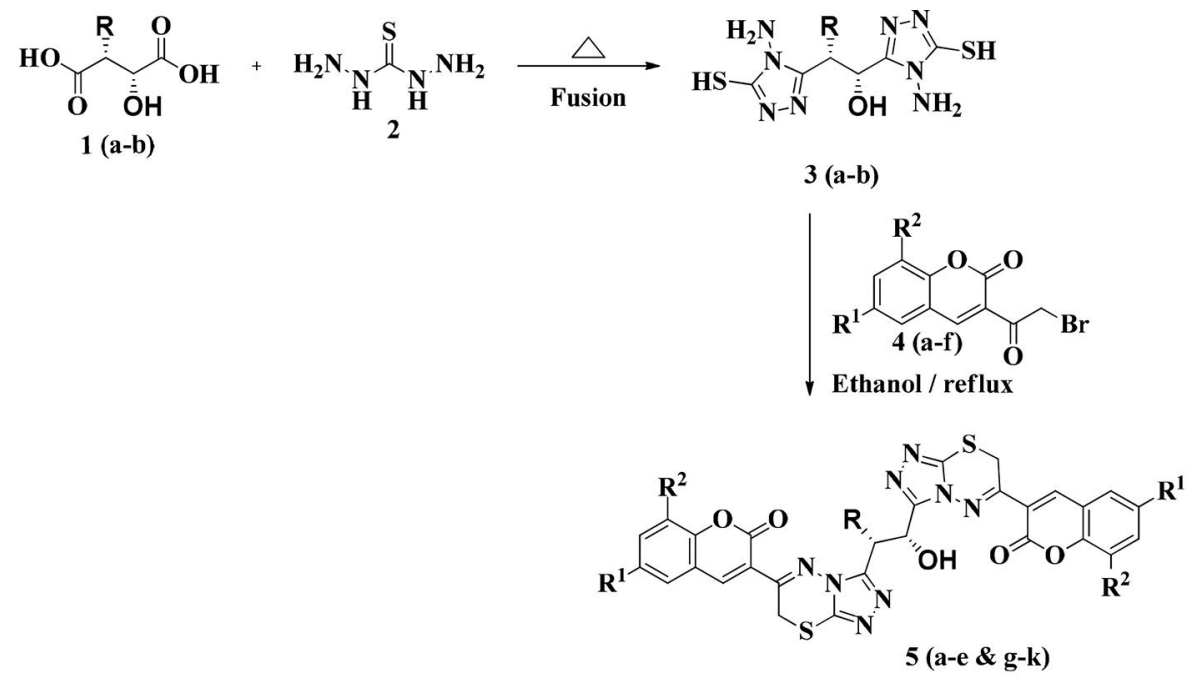<smiles>O=C(O)C(O)C(O)C(=O)O</smiles>

1 (a)<smiles>NNC(=S)NN</smiles>

2

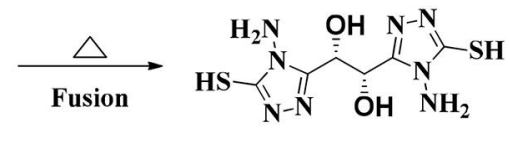

3 (a)<smiles></smiles>

Scheme 1. Synthesis of bis coumarinyl bis triazolothiadiazinyl ethane derivatives (5a-k).

The IR spectrum of compound 5a exhibits characteristic peaks at $3383 \mathrm{~cm}^{-1}$ which is due to $-\mathrm{OH}$ stretching frequency, band at $1709 \mathrm{~cm}^{-1}$ is due to lactone carbonyl stretching frequency, and $1560 \mathrm{~cm}^{-1}$ is due to $\mathrm{C}=\mathrm{N}$ stretching frequency.

The ${ }^{1} \mathrm{H}-\mathrm{NMR}$ spectrum of compound 5a exhibited characteristic peaks, the peak at 4.14-4.23 ppm as multiplet is due to two aliphatic $-\mathrm{C}-\mathrm{H}$ protons, peak at $5.53 \mathrm{ppm}$ as singlet is due to $\mathrm{S}-\mathrm{CH}_{2}$ of thiadiazine ring, peak at $\delta 6.32 \mathrm{ppm}$ as singlet is due to $-\mathrm{OH}$ proton, all the aromatic protons appeared in the region of $\delta 7.32-7.77 \mathrm{ppm}$ as a multiplet and the C-4 proton of coumarin resonated at $\delta 8.51$ as a singlet. The ${ }^{13} \mathrm{C}-\mathrm{NMR}$ spectrum of compound 5a showed chemical shift for $-\mathrm{SCH}_{2}-$ at $\delta 24.0$, aliphatic carbon resonated at $\delta 65.5$, and the lactone carbonyl carbon resonated at $\delta$ 158.3. The mass spectrum of compound $5 \mathbf{a}$ 
Table 1. Synthesis of bis coumarinyl bis traizolothiadiazinyl ethane derivatives (5a-k).

\begin{tabular}{lllccc}
\hline Product & $\mathrm{R}$ & $\mathrm{R}^{1}$ & $\mathrm{R}^{2}$ & Time $^{(\mathrm{h})^{a}}$ & Yield (\%) $^{b}$ \\
\hline $5 \mathrm{a}$ & $\mathrm{OH}$ & $\mathrm{H}$ & $\mathrm{H}$ & 3 & 85 \\
$5 \mathrm{~b}$ & $\mathrm{OH}$ & $\mathrm{Cl}$ & $\mathrm{H}$ & 3.5 & 84 \\
$5 \mathrm{c}$ & $\mathrm{OH}$ & $\mathrm{H}$ & $\mathrm{OCH}_{3}$ & 3.5 & 78 \\
$5 \mathrm{~d}$ & $\mathrm{OH}$ & $\mathrm{Br}$ & $\mathrm{H}$ & 3 & 80 \\
$5 \mathrm{e}$ & $\mathrm{OH}$ & $\mathrm{Br}$ & $\mathrm{Br}$ & 4 & 85 \\
$5 \mathrm{~g}$ & $\mathrm{H}$ & $\mathrm{H}$ & $\mathrm{H}$ & 3.5 & 84 \\
$5 \mathrm{~h}$ & $\mathrm{H}$ & $\mathrm{Cl}$ & $\mathrm{H}$ & 4 & 80 \\
$5 \mathrm{i}$ & $\mathrm{H}$ & $\mathrm{H}$ & $\mathrm{OCH}_{3}$ & 3 & 75 \\
$5 \mathrm{j}$ & $\mathrm{H}$ & $\mathrm{Br}$ & $\mathrm{H}$ & 4 & 80 \\
$5 \mathrm{k}$ & $\mathrm{H}$ & $\mathrm{Br}$ & $\mathrm{Br}$ & 4 & 82 \\
\hline
\end{tabular}

Reaction conditions: Step 1. Aliphatic dicarboxylic acids $1(\mathrm{a}-\mathrm{b})(1 \mathrm{mmol})$ and thiocarobohydrazide 2 (2 mmol) fusion method 10-15 min. Step 2. Ethane-1,2-diyl bis (4-amino-4H-1,2,4-triazole-3-thiols 3a-b (1 mmol) and substituted 3-(2-bromoacetyl) coumarins $4 \mathrm{a}-\mathrm{j}(2 \mathrm{mmol})$, ethanol, $3-4 \mathrm{~h}$.

${ }^{a}$ Overall reaction time $\mathrm{b}$.

${ }^{b}$ Isolated yield in the second step.

showed a molecular ion peak at $m / z$ 627. The spectral data of some of the compounds are given in the following.

\section{Anti-viral activity of novel bis coumarinyl bis triazolothiadiazinyl ethane derivatives}

The newly synthesized bis coumarinyl bis triazolothiadiazinyl ethane derivatives were evaluated for their antiviral activity against a broad spectrum of RNA and DNA viruses [Herpes simplex virus-1 (KOS), Herpes simplex virus-2 (G), Vaccinia virus, Vesicular stomatitis virus, Herpes simplex virus-1TK KOSACV ${ }^{r}$, Adenovirus-2, Vesicular stomatitis virus, Coxsackie virus B4, Respiratory syncytial virus, Para-influenza-3 virus, Reovirus-1, Sindbis virus, Punta Torovirus, Feline Corona Virus (FIPV), Feline Herpes Virus, Influenza A H1N1 subtype, Influenza A H3N2 subtype, Influenza B] in HEL, HeLa, Vero, and CRFK cell medium. Out of all 11 synthesized molecules, 5f exhibited good antiviral activity against influenza A virus. The antiviral activity of all the synthesized novel molecules against influenza virus is shown in Table 2. More specifically, in cytopathic effect (CPE) reduction assay against influenza virus infected Madin-Darby canine kidney (MDCK) cells, $5 \mathbf{f}$ displayed antiviral $\mathrm{EC}_{50}$ values of 20-72 (Table 2).

\section{Molecular docking studies}

The objective of docking simulation study is to understand the possible interactions between synthesized coumarin derivatives and selected target protein against H1N1 virus. The antiviral activity of bis coumarinyl bis triazolothiadiazinyl ethane derivatives is often associated with its ability to inhibit the H1N1 neuraminidase enzyme through the formation of different types of molecular interactions and which helps to derive the structure-activity relationship (SAR) property of the compounds having good antiviral activity. The molecular docking results reveal that the binding affinity of all the novel 11 bis coumarinyl bis triazolothiadiazinyl ethane derivatives are having stronger binding energies than that of the zanamvir (co-crystallized ligand of Protein Data Bank (PDB) molecule) and other marketed known drugs, thereby suggesting promising inhibitory effect for this set of compounds. The binding affinity order of bis coumarinyl bis triazolothiadiazinyl ethane derivatives against the H1N1 neuraminidase receptor is 
Table 2. Antiviral activity of novel compounds against influenza virus-infected $\mathrm{MDCK}^{a}$ cells.

\begin{tabular}{|c|c|c|c|c|c|c|c|c|}
\hline \multirow[t]{3}{*}{ Compound } & \multicolumn{6}{|c|}{ Antiviral $\mathrm{EC}_{50}{ }^{b}(\mu \mathrm{M})$} & \multicolumn{2}{|c|}{ Cytotoxicity $^{c}(\mu \mathrm{M})$} \\
\hline & \multicolumn{2}{|c|}{$\mathrm{A} / \mathrm{H} 1 \mathrm{~N} 1$} & \multicolumn{2}{|c|}{$\mathrm{A} / \mathrm{H} 3 \mathrm{~N} 2$} & \multicolumn{2}{|c|}{ B } & \multirow[b]{2}{*}{ MCC } & \multirow[b]{2}{*}{$\mathrm{CC50}$} \\
\hline & CPE & MTS & CPE & MTS & CPE & MTS & & \\
\hline $5 a$ & $>100$ & $>100$ & $>100$ & $>100$ & $>100$ & $>100$ & $\geq 100$ & $>100$ \\
\hline $5 b$ & $>100$ & $>100$ & $>100$ & $>100$ & $>100$ & $>100$ & 100 & $>100$ \\
\hline $5 c$ & $>100$ & $>100$ & $>100$ & $>100$ & $>100$ & $>100$ & 100 & $>100$ \\
\hline $5 d$ & $>100$ & $>100$ & $>100$ & $>100$ & $>100$ & $>100$ & 20 & 9.2 \\
\hline $5 e$ & $>100$ & $>100$ & $>100$ & $>100$ & $>100$ & $>100$ & 100 & $>100$ \\
\hline $5 f$ & 72 & 45 & 39 & 20 & $>100$ & $>100$ & $>100$ & $>100$ \\
\hline $5 g$ & $>100$ & $>100$ & $>100$ & $>100$ & $>100$ & $>100$ & $>100$ & $>100$ \\
\hline $5 \mathrm{~h}$ & $>100$ & $>100$ & $>100$ & $>100$ & $>100$ & $>100$ & 100 & $>100$ \\
\hline $5 i$ & $>100$ & $>100$ & $>100$ & $>100$ & $>100$ & $>100$ & $>100$ & $>100$ \\
\hline $5 j$ & $>100$ & $>100$ & $>100$ & $>100$ & $>100$ & $>100$ & 20 & 52 \\
\hline $5 k$ & $>100$ & $>100$ & $>100$ & $>100$ & $>100$ & $>100$ & $\geq 0.8$ & 2.6 \\
\hline Zanamivir & 0.40 & 0.40 & 4.0 & 4.9 & 2.4 & 3.0 & $>100$ & $>100$ \\
\hline Ribavirin & 8.9 & 8.9 & 7.8 & 4.5 & 8.9 & 8.4 & $\geq 100$ & $>100$ \\
\hline Amantadine & $\geq 40$ & $\geq 59$ & 1.6 & 2.8 & $>200$ & $>200$ & $>200$ & $>200$ \\
\hline Rimantadine & 24 & 27 & 11.6 & 8.9 & $>200$ & $>200$ & $>200$ & $>200$ \\
\hline
\end{tabular}

${ }^{a}$ MDCK: Madin-Darby canine kidney cells. The influenza virus strains were: A/Ned/378/05 (A/H1N1); A/HK/7/87 (A/H3N2); and $\mathrm{B} / \mathrm{Ned} / 537 / 05$ (influenza B).

${ }^{b}$ Antiviral activity was defined as the $\mathrm{EC}_{50}$ value, i.e., compound concentration producing $50 \%$ inhibition of virus-induced cytopathic effect (CPE), as assessed by microscopy or by the MTS cell viability assay.

${ }^{c}$ Cytotoxicity was expressed as the minimal cytotoxic concentration (MCC; assessed by microscopy) or the $50 \%$ cytotoxic concentration ( $\mathrm{CC}_{50}$; assessed by the MTS cell viability assay).

$\mathbf{5 f}>\mathbf{5 d}>\mathbf{5 h}>\mathbf{5 k}>\mathbf{5 g}>\mathbf{5 b}>\mathbf{5 j}>\mathbf{5 e}>\mathbf{5 i}>\mathbf{5 a}>\mathbf{5 c}>$ amantadine $>$ rimantadine $>$ ribavirin and zanamivir and with the range of MoleDock score -173.36 to -119.16 . The docking results are given in Table 4.

The molecular docking simulation study results show that the catalytic unit of H1N1 neuraminidase active site residues Tyr406, Arg118, Arg292, Trp178, and Arg152 are actively participating in hydrogen bonding with the ligands, belong to key interacting amino acids. The number of hydrogen bonds varies from zero to three. There are other kinds of interactions, electrophilic and hydrophobic, and are responsible to form strong bonds between ligand and receptor (3beq.pdb) to suppress the function of enzyme and responsible to cause the antiviral effect. The binding energies for the synthesized molecules bis coumarinyl bis triazolothiadiazinyl ethane derivatives are showing similarity with the screened antiviral activity results. The ligand $\mathbf{5 f}$ exhibiting good MoleDock score $(-173 \mathrm{kcal} / \mathrm{mole})$ as compared to the known marketed drugs and pdb-bound ligand zanamvir $(-119 \mathrm{kcal} / \mathrm{mole})$. All the docked confirmations well occupied the same active site

Table 3. Anti influenza viral activity of compound $5 f$ against various influenza viruses.

\begin{tabular}{|c|c|c|c|c|c|c|c|c|}
\hline \multirow[b]{3}{*}{ Compound } & \multicolumn{2}{|r|}{ Cytotoxicity } & \multicolumn{6}{|c|}{ Antiviral $\mathrm{EC} 50^{c}(\mu \mathrm{M})$} \\
\hline & \multirow[b]{2}{*}{$\begin{array}{c}\mathrm{CC}^{\circ} 0^{\circ} \\
(\mu \mathrm{M})\end{array}$} & \multirow{2}{*}{$\begin{array}{c}\text { Minimum } \\
\text { cytotoxic } \\
\text { concentration }^{b}(\mu \mathrm{M})\end{array}$} & \multicolumn{2}{|c|}{ InfluenzaA H1N1 subtype } & \multicolumn{2}{|c|}{ Influenza A H3N2 subtype } & \multicolumn{2}{|c|}{ Influenza B } \\
\hline & & & $\begin{array}{l}\text { Visual CPE } \\
\text { score }\end{array}$ & MTS & $\begin{array}{l}\text { Visual CPE } \\
\text { score }\end{array}$ & MTS & $\begin{array}{l}\text { Visual CPE } \\
\text { score }\end{array}$ & MTS \\
\hline $5 f$ & $>100$ & $>100$ & 72.5 & 44.85 & 39.5 & 20.45 & $>100$ & $>100$ \\
\hline Zanamivir & $>100$ & $>100$ & 0.4 & 0.4 & 4 & 4.9 & 2.4 & 3.05 \\
\hline Ribavirin & $>100$ & $\geq 100$ & 8.9 & 8.85 & 7.85 & 4.5 & 8.9 & 8.4 \\
\hline Amantadine & $>200$ & $>200$ & $\geq 40$ & $\geq 59$ & 1.6 & 2.75 & $>200$ & $>200$ \\
\hline Rimantadine & $>200$ & $>200$ & 24 & 26.7 & 11.65 & 8.95 & $>200$ & $>200$ \\
\hline
\end{tabular}

${ }^{a}$ The $50 \%$ cytotoxic concentration (CC50; assessed by the MTS cell viability assay).

${ }^{b}$ The minimal cytotoxic concentration (MCC; assessed by microscopy).

${ }^{c}$ Antiviral activity was defined as the EC50 value, i.e., compound concentration producing $50 \%$ inhibition of virus-induced cytopathic effect (CPE), as assessed by microscopy or by the MTS cell viability assay. 
Table 4. Docking results of bis coumarinyl bis triazolothiadiazinyl ethane derivatives.

\begin{tabular}{|c|c|c|c|}
\hline \multicolumn{4}{|c|}{$5 f$} \\
\hline Compound & MoleDock score & Hydrogen bond energy & No. of hydrogen bonds \\
\hline $5 a$ & -154.067 & -17.21 & 18 \\
\hline $5 b$ & -162.825 & -13.27 & 8 \\
\hline $5 c$ & -151.934 & -4.84 & 7 \\
\hline $5 d$ & -170.139 & -5.60 & 9 \\
\hline $5 e$ & -158.985 & -7.00 & 8 \\
\hline $5 f$ & -173.359 & -13.45 & 13 \\
\hline $5 g$ & -165.171 & -7.65 & 7 \\
\hline $5 \mathrm{~h}$ & -169.913 & -3.93 & 7 \\
\hline $5 i$ & -155.841 & -6.97 & 8 \\
\hline $5 j$ & -160.929 & -6.78 & 9 \\
\hline $5 k$ & -167.636 & -12.96 & 11 \\
\hline Amantadine (2130) & -55.4961 & -0.34 & 2 \\
\hline Rimantadine (5071) & -63.997 & -2.23 & 2 \\
\hline Ribavirin (37542) & -93.8854 & -13.08 & 10 \\
\hline Zanamivir (60855) & -119.161 & -9.085 & 14 \\
\hline
\end{tabular}

The compound is exhibiting highest MoleDock score and hydrogen bonding affinity against H1N1 neuraminidase receptor as compared to standard antiviral drugs.

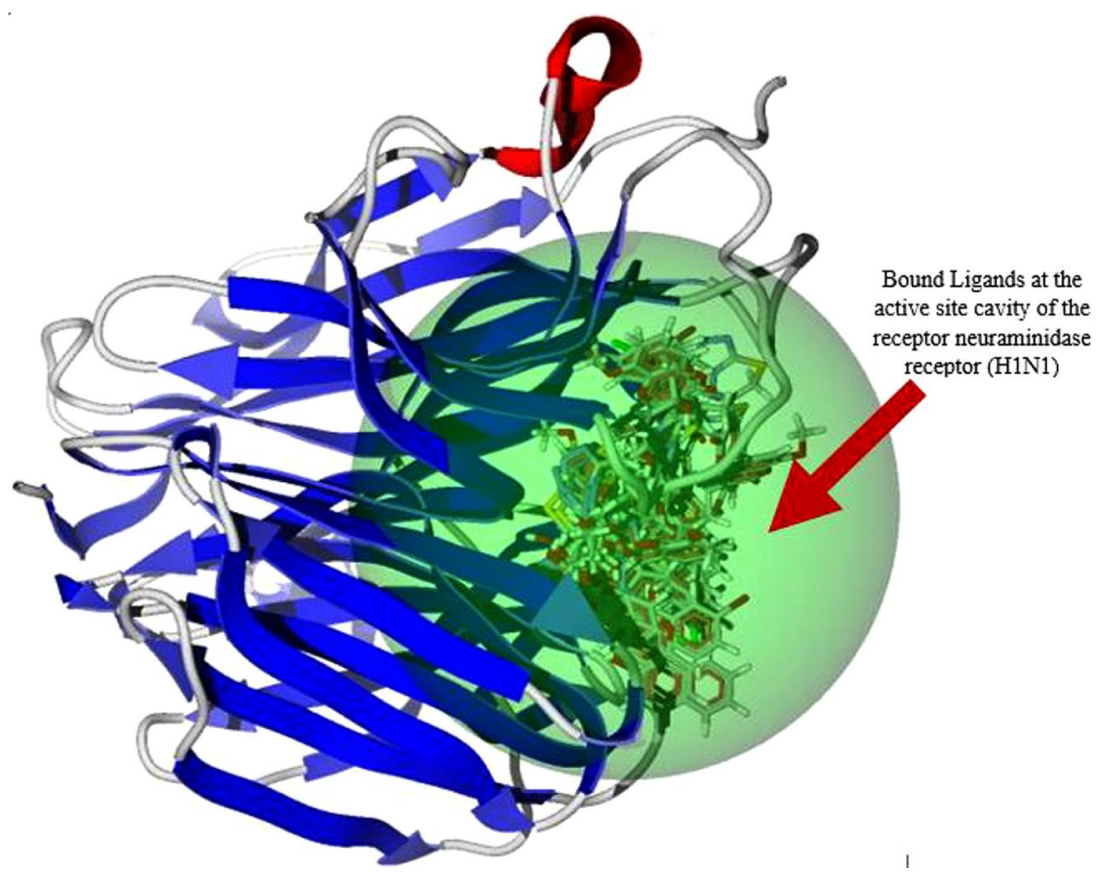

Figure 1. Secondary structure (cartoon) representation of target H1N1 neuraminidase enzyme together with the docked conformation of novel bis coumarinyl bis triazolothiadiazinyl ethane derivatives at the common active site. 


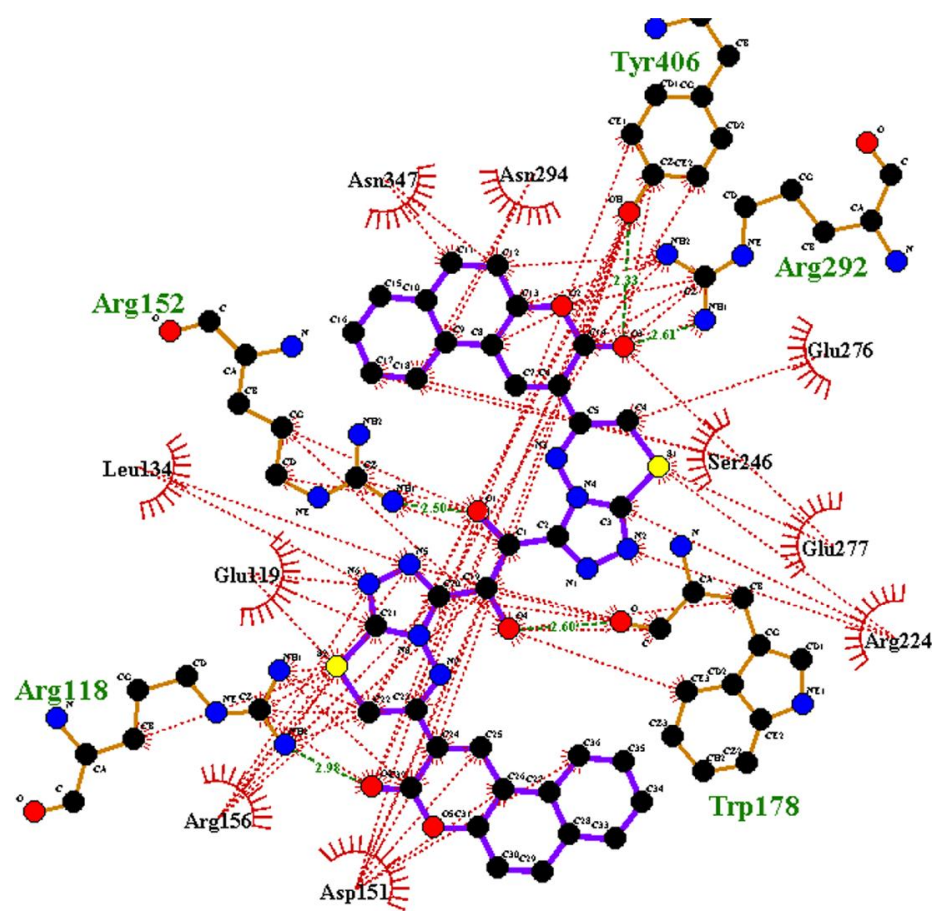

Figure 2. Docked conformation of compound $5 f$ with hydrogen bonding view in the form of $2 \mathrm{D}$ using LigPlus and hydrophilic and hydrophobic interactions at the active site cavity of receptor protein (3beq. pdb). Hydrogen bonds as green color dashed lines between the atoms involved, and hydrophobic contacts as an arc with spokes radiating toward the ligand atoms.

of H1N1 neuraminidase protein and are shown in Figure 1 and the hydrogen bonding, hydrophilic and hydrophobic interactions of compound $\mathbf{5 f}$ at the active site cavity of receptor protein are shown in Figure 2. Surface binding mode of $\mathbf{5} \mathbf{f}$ at the active site of H1N1 neuraminidase is shown in Figure 3.

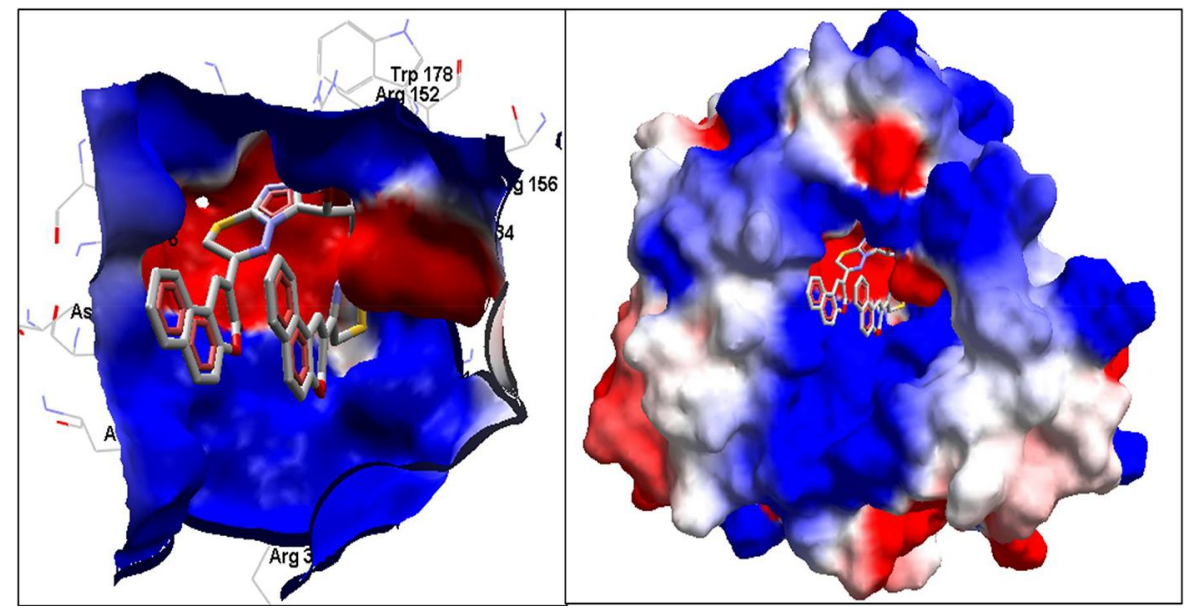

Figure 3. Surface binding mode of $5 f$ at the active site of H1N1 neuraminidase 
The SAR property for antiviral activity of all the bis coumarinyl bis triazolothiadiazinyl ethane derivatives reveals that the compounds having aromatic ring on coumarin nucleus exhibits good antiviral activity against H1N1 A virus and the compounds having other substituents like chlorine, bromine, methoxy, naphthyl on coumarin nucleus are not showing activity against broad spectrum of RNA and DNA viruses.

\section{Experimental}

\section{Chemistry}

All the reagents and solvents were purchased from commercial sources and were used without further purification unless otherwise stated. 3-(2-Bromoacetyl) coumarins ${ }^{[22]}$ were prepared by the literature procedure. The progress of the reaction was monitored by thinlayer chromatography (E. Merck Mumbai, India). Melting points were determined in open capillaries with a "Stuart" melting point apparatus (SMP-30) Mumbai, India and were uncorrected. ${ }^{1} \mathrm{H}$ NMR spectra were recorded on a Bruker WM-400 spectrometer in $\delta$ ppm using TMS as the standard. IR spectra were recorded on a Perkin Elmer 100S instrument (KBr Pellet). Elemental analysis was performed by Carlo Erba EA 1108 automatic elemental analyzer. Electron ionization mass spectra (ESI-MS) were determined on Perkin Elmer (SCIEX API-2000, ESI) at $12.5 \mathrm{eV}$.

\section{General procedure for the synthesis of 1,2-bis (4-amino-5-mercapto-4H-1,2, 4-triazol-3-yl) ethane 1,2-diol/ethanol $(3 a, b)$}

A mixture of acid (l-tartaric acid or malic acid) $(1 \mathrm{mmol})$ and thiocarbohydrazide $(2 \mathrm{mmol})$ was taken in a round-bottom flask and the reaction mixture was fused on a mantle at $180^{\circ} \mathrm{C}$ for about $15 \mathrm{~min}$. After the completion of reaction, the reaction mixture was cooled to room temperature and the excess dicarboxylic acid was removed by aq. $\mathrm{NaHCO}_{3}$ solution. The product was filtered, washed with water, and recrystallized from ethanol.

\section{General procedure for the synthesis of 3,3'-(3,3'-(dihydroxy/hydroxyethane-1, 2-diyl)bis(7H-[1,2,4]triazolo[3,4-b][1,3,4]thiadiazine-6,3-diyl))bis(2H-chromen- 2-one) (5a-k)}

A mixture of 1,2-bis (4-amino-5-mercapto-4H-1,2,4-triazol-3-yl)ethane 1,2-diol/ethanol (3a, b) (1 mmol) and various 3-(2-bromoacetyl)-2H-chromen-2-ones $(2 \mathrm{mmol})$ was refluxed in ethanol. After the completion of reaction (checked through TLC), the reaction mixture was cooled to room temperature. The isolated product was filtered, washed with water, and recrystallized from ethanol.

\section{Spectral characterization data of compound $5 a$}

3,3'-(3,3'-(1,2-Dihydroxyethane-1,2-diyl)bis(7H-[1,2,4]triazolo[3,4-b][1,3,4]thiadiazine6,3-diyl))bis(2H-chromen-2-one) (5a)

mp: $226-228^{\circ} \mathrm{C}$. FT-IR (KBr, $\left.\cup_{\max }, \mathrm{cm}^{-1}\right): 3383(\mathrm{OH}), 1709(\mathrm{C}=\mathrm{O}), 1560(\mathrm{C}=\mathrm{N}), 1607$ $(\mathrm{C}=\mathrm{C}) ;{ }^{1} \mathrm{H}$ NMR (DMSO- $\left.d_{6}, 400 \mathrm{MHz}\right) \delta 4.14-4.23(\mathrm{~m}, 2 \mathrm{H}, \mathrm{CH}), 5.53\left(\mathrm{~s}, 4 \mathrm{H}, \mathrm{SCH}_{2}\right)$, $6.32(\mathrm{~s}, 2 \mathrm{H}, \mathrm{OH}), 7.32-7.39(\mathrm{~m}, 4 \mathrm{H}, \mathrm{ArH}), 7.68(\mathrm{t}, 2 \mathrm{H}, J=7.8 \mathrm{~Hz}, \mathrm{ArH}), 7.77$ (d, 2H, $J=7.6 \mathrm{~Hz}, \mathrm{ArH}), 8.51$ (s, 2H, C-4 proton of coumarin); ${ }^{13} \mathrm{C}$ NMR (DMSO, $100 \mathrm{MHz}$ ): $\delta_{\mathrm{C}}$ 24.0, 65.5, 116.1, 117.9, 122.2, 124.9, 129.5, 133.7, 141.0, 144.3, 152.6, 152.7, 153.6, 158.3; 
ESI-MS, $m / z(\%)$ : $627(\mathrm{M}+1)$; Anal. Calcd. for $\mathrm{C}_{28} \mathrm{H}_{18} \mathrm{~N}_{8} \mathrm{O}_{6} \mathrm{~S}_{2}$, C, 53.67; $\mathrm{H}, 2.90$; N, 17.88\%. Found: C, 53.42; H, 2.84; N, 17.79 .

\section{Biology}

\section{Antiviral activity assay}

The compounds were evaluated for inhibitory activity against human influenza virus in a CPE reduction assay, reported in detail elsewhere. ${ }^{[23]}$ Briefly, subconfluent cultures of MDCK cells in 96-well plates were incubated with influenza virus (see legend of Table 1 for a description of the virus strains used) and serial dilutions of the test compounds, during 4 days of incubation at $35^{\circ} \mathrm{C}$. Four known inhibitors of influenza virus, i.e., zanamivir, ribavirin, amantadine, and rimantadine were included as the reference agents. The antiviral activity and cytotoxicity were determined by microscopic evaluation and MTS cell viability assay. The data were expressed as explained in the legend of Table 1.

\section{Computational studies}

The three-dimensional X-ray crystal structure of H1N1 neuraminidase ${ }^{[24]}$ (PDB ID: 3BEQ) was downloaded from the protein data bank. The downloaded protein was complexed with inhibitor zanamvir at the active site of the target neuraminidase protein. Chemsketch was used to draw the $2 \mathrm{D}$ structure of ligands ${ }^{[25]}$ and converted into energy-minimized 3D structure using Chimera software. ${ }^{[26]}$ The molegro virtual docker model of CLC BIO work bench was used for the preparation of protein structure and selected ligand as an input file docking simulation. ${ }^{[27]}$

The crystallized heteroatoms like ligands and water molecules were removed, missing hydrogen atoms and charge were added to the protein. All the eleven newly synthesized bis coumarinyl bis triazolothiadiazinyl ethane derivatives were docked at the active site region of protein which was already co-crystallized with the ligand (Zanamvir binding site). To substantiate the in vitro antiviral results, the docking results were analyzed and the important SAR properties also elucidated.

Molegro virtual docker was used for docking simulation with all the rotatable bonds of the ligands. The docking conformation of the ligands with good binding affinity was demonstrated in two- and three-dimensional form using LigPlus ${ }^{[28]}$ and Molegro Molecular Viewer. ${ }^{[27]}$

\section{Conclusion}

Coumarin is a naturally occurring molecule with broad-spectrum therapeutic application which is taken as a lead molecule and synthesizes a series of novel bis coumarinyl bis triazolothiadiazinyl ethane derivatives in high yields. All the synthesized compounds were screened for their antiviral activity in vitro and validated through docking simulation method. The compound $\mathbf{5 f}$ displayed good binding affinity against the selected target neuraminidase enzyme and suggested that $\mathbf{5} \mathbf{f}$ can act as lead for the synthesis of some more potent derivatives against influenza virus.

\section{Funding}

The authors are very thankful to the authorities of National Institute of Technology, Warangal and the KU Leuven (GOA/15/019/TBA) for providing financial assistance and laboratory facilities, and Lizette Van Berckelaer and Leentje Persoons for excellent technical assistance. 


\section{References}

[1] Colak, A. T.; Colak, F.; Atar, A.; Olgun, A. Acta Chem. Solv. 2010, 57(1), 212-221.

[2] Rohini, R.; Reddy, P. M.; Shanker, K.; Ravinder, V. Acta Chem. Solv. 2009, 56, 900-907.

[3] Rajasekaran, S.; Rao, G. K.; Pai, S. P. N.; Ranjan, A. Int. J. Chem. Tech. Res. 2011, 3(2), 555-559.

[4] Elnagdi, M. H.; Abdallah, S. O.; Ghoneim, K. M.; Ebied, E. M.; Kassab, K. N. J. Chem. Res. 1997, (2), 44-45.

[5] Chimichi, S.; Boccalini, M.; Cosimelli, B.; Viola, G.; Vedaldi, D.; Dall Acqua, F. Tetrahedron Lett. 2002, 43, 7473-7476.

[6] Bhat, M. A.; Siddiqui, N.; Khan, S. A. Indian J. Pharm. Sci. 2006, 68, 120-124.

[7] Zhao, H.; Neamati, N.; Huixiao, H.; Mazumder, A.; Wang, S.; Sunder, S.; Pommier, Y.; Burke, T. R. J. Med. Chem. 1997, 40(2), 242-249.

[8] Williams, J. L. R.; Specht, D. P.; Farid, S. Polym. Eng. Sci. 1983, 23, 1022-1024.

[9] Zabradnic, M. The Production and Application of Fluorescent Brightening Agents; John Wiley and Sons: New York, 1992.

[10] O'kennedy, R.; Thornes, R. D. Coumarins: Biology Application and Mode of Action; John Wiley and Sons: Chichester, 1997.

[11] Collins, C. B.; Taylor, K. N.; Lee, F. W. Opt. Commun. 1978, 26, 101-102.

[12] Mir, I.; Siddiqui, M. T.; Comrie, A. Tetrahedron 1970, 26(22), 5235-5238.

[13] Yale, H. L.; Piala, J. J. J. Med. Chem. 1966, 9(1), 42-46.

[14] Mhasalkar, M. Y.; Shah, M. H.; Nikam, S. T.; Anantanarayanan, K. G.; Deliwala, C. V. J. Med. Chem. 1970, 13(4), 672-674.

[15] Brucato, A.; Coppola, A.; Gianguzza, S.; Provenzano, P. M. Boll. Soc. Ital. Biol. Sper. 1978, 54, 1051-1057.

[16] Coffen, D. L.; Fryer, R. I. Process for Preparing Triazolobenzodiazepines. U. S. Patent 3849434 , 1974 (Chem. Abstr. 1975,82, 73044v).

[17] Shiroki, M.; Tahara, T.; Araki, K. Jap. Patent 75100096, 1975 (Chem. Abstr., 1976, 84, 59588k).

[18] Gupta, R.; Paul, S.; Gupta, A. K.; Kachroo, P. L. Indian J. Chem. 1994, 33B, 888-891.

[19] Sunil, D.; Isloor, A. M.; Shetty, P.; Satyamoorthy, K. A.; Prasad, S. B. Arabian J. Chem. 2010, 3, 211-217.

[20] Rehse, K.; Brummer, U.; Unsold, E. Die Pharm. 1998, 53(12), 820-824.

[21] El Shehry, M. F.; Abu-Hashem, A. A.; El-Telbani, E. M. Eur. J. Med. Chem. 2010, 45(5), 1906-1911.

[22] Rajeswar Rao, V.; Padmanabha Rao, T. V. Indian J. Chem. 1986, 25B, 413-415.

[23] Vanderlinden, E. F.; Goktas, Z.; Cesur, M.; Froeyen, M. L.; Reed, C. J.; Cesur, N.; Naesens, L. J. Virol. 2010, 84(9), 4277-4288.

[24] Xiaojin, X.; Xueyong, Z.; Raymond, A. D.; James, S.; Wilson, I. A. J. Virol. 2008, 82(21), 10493-10501.

[25] Advanced Chemistry Development, Inc. ACD/ChemSketch, version 8.0. Advanced Chemistry Development, Inc.: Toronto, ON, Canada, 2006. http://www.acdlabs.com. (accessed on 16 August, 2017)

[26] Pettersen, E. F.; Goddard, T. D.; Huang, C. C.; Couch, G. S.; Greenblatt, D. M.; Meng, E. C.; Ferrin, T. E. UCSF Chimera - A Visualization System for Exploratory Research and Analysis. J. Comput. Chem. 2004, 25, 1605.

[27] Thomsen, R.; Christensen, M. H. MolDock: A New Technique for High-Accuracy Molecular Docking. J. Med. Chem. 2006, 49(11), 3315-3321.

[28] Laskowski, R. A.; Swindells, M. B. LigPlot ${ }^{+}$: Multiple Ligand-Protein Interaction Diagrams for Drug Discovery. J. Chem. Inf. Model. 2011, 51, 2778-2786. 